\title{
TRANSPORTE NASAL DE staphylococcus aureus EN TRABAJADORES DE LA SALUD: PRIMER INFORME DE UN IMPORTANTE HOSPITAL PÚBLICO EN ARGENTINA
}

\author{
Nash transport of staphylococcus aureus in health workers: first report of an important public hospital in \\ Argentina
}

\author{
Jhojhan Castillo Rivas $1, \mathrm{a}$, , \\ 1 Escuela profesional de Medicina, Universidad Andina del Cusco, Cusco, Perú. \\ a Estudiante de Medicina \\ ”013100763B@uandina.edu.pe
}

Citar como: Castillo, J. (2018). Transporte nasal de staphylococcus aureus en trabajadores de la salud: primer informe de un importante hospital público en argentina (carta al editor). Rev Yachay, 7(1), 499-500.

Recibido: 16-09-2018; Aceptado 07-12-2018

Señor editor

Las investigaciones realizadas al respecto, se publican bajo el título «Transporte nasal de Staphylococcus aureus en trabajadores de la salud: primer informe de un importante hospital público en Argentina», en el número 2 del vol. 49 (2017) de la Revista Argentina de Microbiología, cuyos autores son; Carina Andrea Boncompain y colaboradores.

$\mathrm{Al}$ revisar este artículo, advertimos que menciona que el Staphylococcus aureus es una bacteria fácilmente adquirida por el personal de salud y es el responsable de numerosas infecciones en el ser humano, evoca su estudio en la tasa de portación nasal de esta bacteria y la resistencia a la meticilina por parte de los médicos, enfermeras y tecnólogos médicos.

Sin embargo, y con el debido respeto, consideramos prudente apuntar que la resistencia a la meticilina está dada por PBP-2a, que es una proteína de unión a la penicilina codificada por el gen mecA, y que también se han descrito tres mecanismos que explican la resistencia de Staphylococcus aureus, a $\beta$-lactámicos, como es la hiperproducción de las $\beta$-lactamasas, la modificación de las PBP y la resistencia intrínseca de la meticilina, lo cual permite que el organismo crezca y pueda dividirse en la presencia de la meticilina y algunos antibióticos betalactámicos.

El gen mecA se encuentra en el elemento genético móvil llamado 'casete cromosómico estafilocócico' (SCCmec), cabe señalar también, que el gen mec está ausente de las cepas susceptibles y está presente en todas las cepas resistentes y, que el SARM es uno de los pocos agentes patógenos que habitualmente están implicados en casi todos los tipos de infecciones adquiridas en el hospital, como lo menciona Deverick J Anderson, en su artículo.

Es por ello que las cepas de $S$. aureus, resistentes a la meticilina asociadas a la atención médica (HA-MRSA), se transmiten con mayor frecuencia en el personal médico y personal de salud, la colonización con $S$. aureus aumenta el riesgo de infección después de procedimientos médicos o quirúrgicos invasivos, hemodiálisis; después de un contacto directo con pacientes inmunosuprimidos que puedan presentar impétigo, foliculitis, celulitis y demás afecciones en la piel, transmitiéndose de esta manera, en el personal médico a través de las manos transitoriamente contaminadas y, posteriormente llevada hacia la parte de las vías respiratorias. Cabe señalar también que el Staphylococcus aureus es el responsable de una amplia gama de manifestaciones clínicas en los pacientes, que van desde infecciones de la piel relativamente benignas, hasta afecciones potencialmente mortales: como la endocarditis bacteriana y la osteomielitis.

Apoyando esta posición, habría que realizar un análisis molecular y genético para poder identificar este gen en el personal de salud portador de esta bacteria pudiendo así concluir que el staphylococcus aureus es un potente patógeno causante de diferentes afecciones en el ser humano, siendo el principal foco de exposición el personal de salud, y la resistencia a la meticilina está dada por diferentes mecanismos relacionados a la PBP-2a y al gen mecA. 


\section{Referencias bibliográficas}

Deverick J. Anderson (2018). Staphylococcus aureus: Resistente a la meticilina (SARM) en adultos. Estados Unidos. JAMA jul. (298) 1763.

Kreiswirth B, Kornblum J, Arbeit RD, y col. (2018). Evidencia de un origen clonal de la resistencia a la meticilina en Staphylococcus aureus. Science: (259) 227.

Archer GL, Niemeyer DM, Thanassi JA, Pucci MJ. (2017). Diseminación entre estafilococos de secuencias de ADN asociadas con resistencia a meticilina. Antimicrob Agents Chemother; (38) 447.

Boyce JM. (2017). Staphylococcus aureus resistente a la meticilina en hospitales y centros de atención a largo plazo: microbiología, epidemiología y medidas preventivas. Infect Control Hosp Epidemiol. Estados Unidos. JAMA (13) 725.
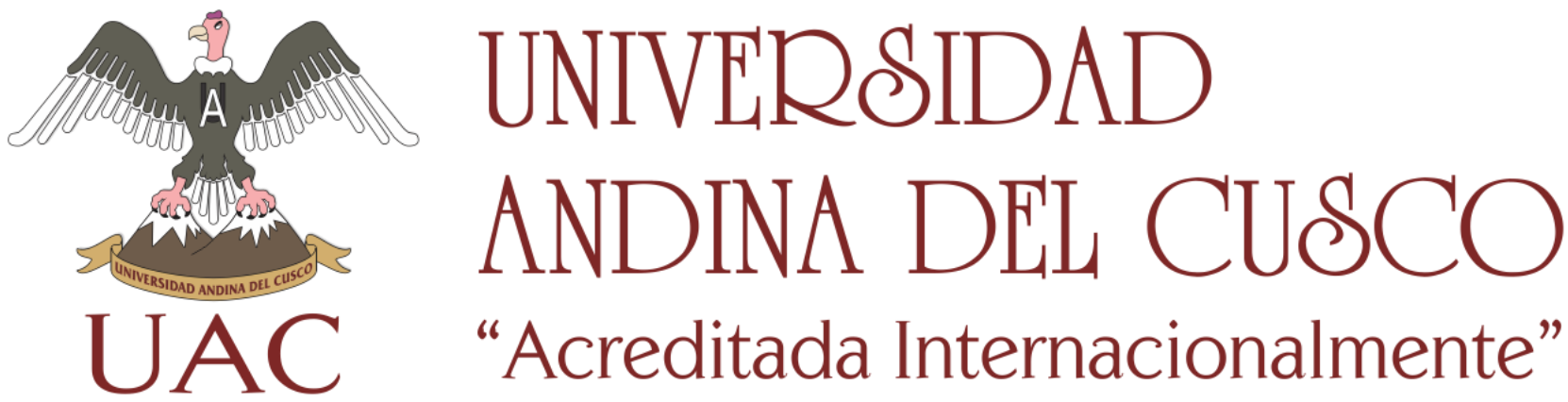

"Acreditada Internacionalmente" 